\title{
Mudge, Stephanie L. Leftism Reinvented. Western Parties from Socialism to Neoliberalism. Harvard University Press, Cambridge (MA) 20I8. 560 pp. \$39.95; £28.95; € 36.00.
}

As the main democratic political force behind the move towards greater social justice and equality during the twentieth century, social democratic parties have long received a tremendous amount of attention from historians, political scientists, and sociologists. In recent decades, much of this attention has focused on what has often been perceived as a major shift in social democratic policy, or even ideology: since the i 990 , nearly all social democratic parties have presided over policies that privatized parts of the public sector, deregulated major markets, and partially recommodified labour by limiting access to welfare state programmes. In some countries, the "traditional left" did so more wholeheartedly than in others. Yet, no major social democratic or left party has been completely immune to the advocates of market liberalization, and this raises the question why parties whose raison d'être is to create the conditions for capitalism to produce greater egalitarian and solidaristic outcomes have come to accept part of the neo-liberal agenda in recent decades.

In an excellent new book on the twentieth-century evolution of four major left parties the British Labour Party, German Social Democratic Party (SDP), Swedish Social Democratic Party (SAP), and US Democratic Party - the sociologist Stephanie Mudge seeks to shed new light on this question. Based on a thorough analysis of biographies, news sources, and party publications, Mudge analyses internal debates in these parties through a "refraction account" that focuses on the role of intra-party networks and relationships, the worldview of party spokespeople, and intellectuals in shaping party policy, and does so from different analytical perspectives. While one of Mudge's goals is to explain the rise of "neoliberalized leftism" in both Europe and the United States, she also focuses on previous transformations of the four parties. The book consequently has much to offer and could also be read for the interesting histories of the Labour Party, SPD, SAP, and Democratic Party that it provides.

In line with conventional thinking on the development of social democratic parties, Mudge distinguishes three different historical periods. The first covers the emergence of social democratic parties in Europe during the late nineteenth and early twentieth centuries and discusses their socialist origins. The second ranges roughly from the i930s to the I960s, when the three European social democratic parties gradually replaced their socialist origins and - like the Democratic Party in the United States - came to embrace the doctrine of Keynesianism, with its emphasis on deficit financing and commitment to full employment. The final period identified by Mudge starts in the I970s and culminates in the "third way" politics of the I990s, when all four parties analysed in the book came to pursue policies that constituted a synthesis of traditional left and centre-right economic thinking.

Mudge's main theoretical claim is that each of these periods was characterized by different types of party experts whose thinking not only reflected existing party ideology, but also helped to shape it. She consequently sets out to explain how the emergence of new types of party experts drove the programmatic vocabularies of left parties and, by extension, the two main transformations of these parties, during the twentieth century. According to Mudge, the first of these transformations occurred as professional economists schooled in Keynesian thinking - whom she names "economist theoreticians" - came to replace the mostly non-academic socialist "party theoreticians" of the early twentieth century. She further argues that the second transformation was in turn crucially linked to the emergence of a 
new type of centre-left economist who was not necessarily professionally grounded in the academic world, and who maintained close bonds with domestic and international financial institutions. According to Mudge, these transnational, finance-oriented economists (or TFEs) differed from the Keynesian economist theoreticians of the mid-twentieth century in that they were bearers of a neo-liberal ethic who spoke for markets rather than for particular societal groups, such as workers.

Mudge outlines her argument with an interesting analysis of inter-party discussions that is often quite rich in detail. For instance, she explains how in 1932 Rudolf Hilferding, the SPD's leading theoretician at the time, used his influence to block a proposal for large-scale public spending by a group of young economists that could have reversed the rising unemployment in Germany at the time - and which might consequently have averted Adolf Hitler's rise to power the subsequent year. She contrasts this with the situation in Sweden, where the SAP did embrace a successful deficit-spending crisis programme in the I930s, which enabled it to build long-term alliances with centre-right parties such as the Farmer's Party. Her analysis of events in Britain and the United States similarly shows how young, Keynesian-oriented progressive economists clashed with the old guard that remained wedded to more orthodox economic prescriptions.

Of course, these insights are by no means new. Of greater conceptual importance is therefore Mudge's claim that the embrace of market-friendly policies by all four parties during the I $990 \mathrm{~s}$ directly related to shifts in the mainstream economics profession that produced a more finance-oriented economist. Mudge crucially holds that the emergence of this new type of economist thus not only affected the policy orientation of centre-right parties; she argues that "the most significant historical change in post-1970s Western political language was on the left - not on the right" (p. 45). This is a rather bold statement that sets her apart from much of the existing literature on party change. For instance, over the years many studies have argued that the most important development in US politics since the I970s has been the radical shift to the right of the Republican Party. In addition, it is well-established that the adoption of "third way" or "new left" politics by traditional left parties in the I990s was, at least in part, a response to the successful adoption of neoliberal policies by their centre-right competitors.

An important problem with Mudge's analysis is that it is unclear how it relates to these conventional explanations for the transformation of the left into what she defines as "neoliberalized leftism". Rather than engaging with these explanations in an extensive manner, the book simply states that it "does not reject but rather incorporates these modes of explanation", only to later argue that neither electorate nor economics-driven approaches can account for the content and timing of the market-friendly reforms by the four parties during the I990s. This criticism is far too thin to be persuasive, though. The case studies on the post-I 980 s measures undertaken by various SAP governments in Sweden and the adoption of "new middle" politics by the Schröder government in Germany during the I990s, for instance, lack a serious discussion of the severe economic problems in which both countries found themselves in this period, and the pressure for reform that this created.

In other respects, the case studies are also rather thin and all too often provide interpretations of political events that are not well-substantiated. For instance, many scholars will be surprised to read that the "LO economists" loss of the backing of the mainstream profession" for the introduction of wage earner funds during the late I970s was a sign of "the shifting orientations of Swedish economists" (p. 317). After all, this proposal was far more radical than anything previously proposed in Sweden and clearly conflicted with the well-established principle of government non-interference with industrial relations. Moreover, there is no systematic explanation for the type of policy reform that is analysed in the book. Why, for instance, does the chapter on the 
Clinton administration discuss the creation of NAFTA and the administration's handling of the peso crisis, but not, for instance, its attempt to introduce universal healthcare? Why does it mention Clinton's balanced budget approach but not its 1993 tax reform and resulting increase in the top marginal income tax rate? Finally, the book fails to establish that transnational, finance-oriented economists actually played a major role in the development and implementation of pro-market reform by the four parties - which is a serious omission.

In sum, Mudge's analysis can be challenged on several grounds. That, however, does not obviate the fact that Leftism Reinvented is an impressive book that provides a fascinating overview of the development of four major leftist parties over a period of more than a century. Because of its broad and interdisciplinary approach, the book will be of interest to a wide readership that includes historians, political scientists, and sociologists.

\section{Dennie Oude Nijhuis}

International Institute of Social History Cruquiusweg 31, I0I9 AT Amsterdam, The Netherlands

E-mail: dennie.oudenijhuis@iisg.nl doi:10.1017/S0020859019000440

Global Perspectives on Workers' and Labour Organizations. Ed. by Maurizio Atzeni and Immanuel Ness. [Work, Organization, and Employment.] Springer, Singapore [etc.] 20I 8. xvi, I73 pp. € I 25.34. (E-book: € 95.19)

Global Perspectives on Workers' and Labour Organizations groups nine in-depth and interesting labour studies on both the Global South and Global North, which allow us to see how widespread the precariousness of work is across the globe, as well as the almost everpresent and sometimes effective forms of resistance and self-organization of workers affected by precariousness. Although each study in the book poses different research questions and uses different units of analysis, they share the starting point of critical theoretical frameworks - with Marxism always present. All contributors adopt the perspective of the workers and take as the general context the problem of action and structure: how precariousness can be seen, on the one hand, as an impulse on the part of capital to make and unmake the working class and, on the other, how workers respond to this precariousness. ${ }^{\mathrm{I}}$

Presenting a diversity of national and sectoral studies, the authors look at different forms of self-organization by workers and the unique problems related to each case. After reviewing the individual chapters, I will highlight some of the most interesting sociohistorical hypotheses presented in this volume.

After a theoretical discussion on precariousness and unionization opportunities, in Chapter one Ian Thomas MacDonald presents a series of "firm-centred" and "state-regulated" union strategies developed in the cultural and hospitality industries in the US and Canada. Critical of the "sectionalism" of these strategies, ${ }^{2}$ the author advocates a more politicized and urban form

I. Mario Tronti, Obreros y capital (Madrid, 200I).

2. Stephanie Ross, "Varieties of Social Unionism: Towards a Framework for Comparison", Just

Labour: A Canadian Journal of Work and Society, I I (2007), pp. I6-34. 